\section{HYDROCYANIC ACID AS A BACTERICIDE.}

\section{To the Editor of THE LANCET.}

SIR,-An annotation in your issue of Sept. 23rd uttered a timely warning regarding the danger attending the use of hydrocyanic acid gas as a fumigant in ship disinfection, and questioned whether it was of much value as a germicide. In order to ascertain definitely if such was the case the following simple experiments were conducted.

A broth culture of $B$. typhosus was selected as the test organism, and the solution of hydrocyanic acid (prussic acid) of the British Pharmacopoia was employed as the reagent, and an attempt was made to determine its carbolic acid coefficient. The concentrations of the acid examined would, of course, greatly exceed those which it is possible to realise under fumigation conditions on board ship.

The result of the inquiry proves (vide the accompanying test table) that prussic acid has no measurable carbolic acid coefficient. From a bactericidal standpoint it is too weak to appreciably affect pathogenic germs. Further, strips of sterile filter paper, moistened with the above broth culture, which were suspended in the vapour over the acid in a stoppered bottle for one hour, were found to be unaffected, the strips giving rise to vigorous cultures of $B$. typhosus when placed in sterile broth. Like many of the most virulent animal poisons, such as strychnine, aconitine, \&c., prussic acid is produced by certain of the higher plants, and like them it is not injurious to the lowest plants (bacteria).

As a disinfectant its employment is therefore as fatuous as it is dangerous.

I am, Sir, yours faithfully,

WIITIAM C. REYNOT.DS, D.Sc., F.I.C.

Jeyes' Laboratories, Plaistow, Oct. 2nd, 1922.

Standard Bacteriological Test (Rideal-Walker Method).

\begin{tabular}{|c|c|c|c|c|c|c|c|}
\hline \multirow{2}{*}{ Sample. } & \multirow{2}{*}{$\begin{array}{l}\text { Dilu- } \\
\text { tion. }\end{array}$} & \multicolumn{4}{|c|}{$\begin{array}{l}\text { Time culture exposed } \\
\text { to action of disinfectant } \\
\text { - minutes. }\end{array}$} & \multicolumn{2}{|c|}{ Subcultures. } \\
\hline & & $2 \frac{1}{2}$ & $\tilde{\mathbf{5}}$ & 71 & 10 & $\begin{array}{l}\text { Period of } \\
\text { incubation. }\end{array}$ & $\begin{array}{l}\text { Tempera } \\
\text { ture. }\end{array}$ \\
\hline $\begin{array}{c}\text { Hydro- } \\
\text { cyanic } \\
\text { acid } \\
\text { B.P. } \\
\text { Phenol. }\end{array}$ & $\begin{array}{l}1: 2 \\
1: 4 \\
1: 6 \\
1: 8 \\
1: 105\end{array}$ & $\begin{array}{l}+ \\
+ \\
+ \\
+\end{array}$ & $\begin{array}{l}+ \\
+ \\
+ \\
+ \\
+\end{array}$ & & $\begin{array}{l}+ \\
+ \\
+ \\
+ \\
.\end{array}$ & 48 hours. & $37^{\circ} \mathrm{C}$. \\
\hline
\end{tabular}

Temp. : $15^{\circ}$ C. Date : 2/10/22. Strain B. typhosus used Lister. Rideal-Walker coefficient: Less than 0.02 .

\section{A CASE OF PRIMARY CARCINOMA IN AN INFANT.}

To the Editor of THE LANCET.

SIR,-In connexion with the article in THE LANCET of July 29th on Primary Malignant Growth of the Liver in Infants, by Mr. C. B. Dansie, the accompanying notes of a case which came under the observation of Dr. R. H. Vallance, of Lewes, and myself not long ago seem to merit publication.

The child, N. H., was born on March 15th, 1920, and died on May 13th following. The mother is a healthy woman about 36 years of age, and has two healthy children. She had another child, premature and stillborn. There is no history of either cancer or syphilis on either maternal or paternal side. Dr. Vallance attended at the birth of the child which is the subject of this letter. Labour was normal, and at birth the child appeared perfectly healthy and well developed. It was a full-term baby. In the course of the first ten days after birth the child had a slight discharge of blood from the vagina which lasted about two days, but the actual loss of blood was negligible. The mother thought that the infant was more delicate from birth than her other children, and states that it was from the first unusually drowsy and pale in colour, but there appeared to her to be no reason for calling in a doctor. The child was brought up on the breast. Death took place quite suddenly in the early morning just after a full and apparently normal breast-feed. For some weeks before death there was slight daily sickness, and according to the mother the child's skin gradually became "yellowish-white."
At the autopsy the body was poorly nourished but not emaciated. The weight was $7 \frac{1}{2} \mathrm{lb}$. There was no externa evidence of disease, and internally all the organs of the body appeared perfectly normal with the exception of the liver The liver weighed $10 \frac{1}{2} \mathrm{oz}$., and most of the left lobe was occupied by a growth, roughly spherical in shape, measuring about $2 \frac{1}{2}$ inches in diameter. This growth was firm in consistence and distinctly yellow in colour. There was also a small nodule of similar growth situated in the edge of the right lobe. The stomach was dilated, and contained a considerable quantity of undigested milk. The stomach walls were thin and pale.

A portion of the growth, with some of the surround. ing liver tissue, was forwarded to the Stephen Ralli Memorial Laboratory for examination. Externally the growth was homogeneous ; it was surrounded by a definite zone of hremorrhage. Sections made from the growth showed a fairly abundant fibrous stroma, with numerous imperfectly-defined acini lined with cubical cells. Small isolated groups of degenerated hepatic cells were scattered throughout. At parts there were considerable necrobiotic changes. The microscopic characters generally were those of a primary bile-duct carcinoma of the liver.

I am, Sir, yours faithfully,

H. M. GaLT

Royal Sussex County Hospital, Brighton, Oet. 4th, 1922.

\section{THE ACTION OF VACCINES.}

\section{To the Editor of THE LANCET.}

SIR,-Dr. J. Pratt-Johnson, in a paper with this title in THE LANCET of Oct. 7th, has made certain statements upon which I would like to make a few comments. He apparently maintains that the severe local reaction produced by certain vaccines is an anaphylactic phenomenon. He further states that-

"Erroneous views have been put forward in explanation of the toxicity of vaccines in these cases. These severe reactions have been stated to be due to some peculiar property, rather than to a change in the susceptibility of the patient to the vaccine, and new drastic methods of preparing vaccines have been introduced with the idea of reducing the local reaction and the so-called toxicity of the vaccine (11) The new methods consist of the breaking up of the bacterial bodies by strong chemical solutions aided by mechanical appliances and employing the suspension of the residue as a vaccine (12). The actual effect of this procedure is to weaken enormously the antigenic value of the vaccine, the titre of which is probably a hundred times less than the titre of the original bacterial suspension."

The above quotation is a somewhat scathing attack on my researches on the detoxication of vaccines, since his references to the literature-viz., Nos. 11 and 12 in this quotation-refer to my original papers on this subject. His statements just quoted are, in my opinion, unjustifiable and very misleading, as it appears to me quite erroneous to maintain that the reaction of a vaccine is due to anaphylaxis and that it depends upon the susceptibility of the patient. Patients no doubt vary in suceptibility and he may attempt to explain this variability by anaphylaxis if he likes, but there is no scientific proof that this is the true explanation, and no one even knows the nature of anaphylaxis, which is still a mystery. Apart altogether from the variation in the susceptibility of patients, it is a well-recognised fact that the toxicity or reaction-producing power of a vaccine resides in the vaccine itself, and that the toxicity of a vaccine exists as a thing apart from anaphylaxis. Dr. Pratt-Johnson might as well maintain that the toxicity of cobra venom or the irritant effect of " 606 " injected into the tissues was due to anaphylaxis, or that, because the susceptibility of patients to " 606 " is variable, therefore the reactions produced by "606" were anaphylactic in nature.

Again, I disagree entirely with his statement hat the actual effect of my detoxication procedure " is to weaken enormously the antigenic value of a vaccne, the titre of which is probably at least a hundred tines less than the titre of the original bacterial suspension." Is this an authoritative announcement from Ir. Pratt-Johnson, or is it mere opinion and guesswork? Such a statement, apparently unsupported by carefuly 